\title{
TINJAUAN YURIDIS NORMATIF TERHADAP REGULASI MATA UANG KRIPTO (CRYPTO CURRENCY) DI INDONESIA
}

\author{
M. Najibur Rohman; Program Studi Hukum Program Doktor, \\ Universitas 17 Agustus 1945 Semarang; Jl. Pemuda Nomor 70 Semarang 50132, E-mail: \\ kotaknajib@gmail.com
}

\begin{abstract}
Abstrak
Kemajuan teknologi informasi telah mengubah pola kehidupan ekonomi masyarakat yang mendorong terciptanya budaya ekonomi baru. Perubahan ini tentu saja mendorong adanya perubahan hukum. Salah satu fenomena baru dalam kehidupan ekonomi global adalah kemunculan mata uang kripto. Di Indonesia, mata uang kripto telah menjadi perhatian pemerintah dan menjadi objek yang diatur dalam regulasi. Bagi pemerintah, tantangan utama dalam kebijakan ini adalah menghadirkan regulasi yang memadai dan harmonis sehingga dapat menjadi pedoman bagi kegiatan ekonomi masyarakat. Tujuan dari penelitian ini adalah untuk menjelaskan aspek yuridis normatif terhadap regulasi atau kebijakan mata uang kripto di Indonesia. Tinjauan ini didasarkan pada undang-undang dan sejumlah peraturan untuk melihat legalitas dan bentuk pengaturan mata uang kripto. Penelitian ini menggunakan metode penelitian hukum normatif dengan pendekatan yuridis normatif. Hasil dari penelitian ini menunjukkan bahwa secara yuridis normatif terdapat perbedaan definisi yang berdampak pada pola pengaturan mata uang kripto. Bank Indonesia memandangnya sebagai uang digital sehingga tidak sah sebagai alat pembayaran, sementara Kementerian Perdagangan memandangnya sebagai aset digital sehingga dapat diperdagangkan pada bursa berjangka.
\end{abstract}

Kata Kunci: Mata Uang Kripto, Yuridis Normatif, Regulasi

\begin{abstract}
The advancement of information technology have changed the economic life pattern in community which encouraging a new economic culture. This change, absolutely, encourages the change of law. One of the new phenomena in the life of global economy is the emergence of crypto currency. In Indonesia, crypto currencies have been become a government concern and are subject to be regulated. For the government, the main challenge in this policy is to provide adequate and harmonious regulations so it can be guidelines for economic activities. The purpose of this study is to explain the normative juridical aspects of crypto currency regulation or policy in Indonesia. This review is based on laws and regulations to see the legality and regulation forms of crypto currencies. This study uses a normative legal research method with a normative juridical approach. The result of this study indicates that there are differences in definitions that have an impact on crypto currency regulation in Indonesia. Bank Indonesia views it as digital money so it is not legal as a tool of payment, while the Ministry of Trade views it as a digital asset or commodity so that it can be traded on a mercantile exchange.
\end{abstract}

Keywords: Cryptocurrency, Normative Juridical, Regulation

\section{PENDAHULUAN \\ Latar Belakang}

Salah satu fenomena yang lahir dari rahim revolusi industri 4.0 adalah mata uang kripto (crypto currency). Uang kripto yang didefinisikan sebagai uang digital di era digital (digital cash for the digital age ${ }^{1}$ ini dipandang sebagai sebuah revolusi alat pembayaran dengan tingkat efisiensi dan efektivitas yang mumpuni, berlaku secara global, aman dan terdesentralisasi. Penggunaan uang ini, meskipun masih dalam perdebatan, berkembang pesat karena dampak perkembangan teknologi informasi yang diskemakan sebagai revolusi industri 4.0 tersebut. Berbeda dengan revolusi industri 3.0 yang ditandai dengan penemuan komputer, era ini berkembang dengan optimalisasi komputer melalui koneksi,

${ }^{1}$ https://www.coinbase.com/learn/what-is-cryptocurrency (diakses 7 April 2020). 
komunikasi, dan pembuatan-pembuatan keputusan dengan meminimalisir keterlibatan manusia. $^{2}$

Perhatian terhadap perkembangan mata uang kripto ini selaras dengan perkembangan lingkungan masyarakat yang semakin kental dengan penggunaan teknologi dan alat-alatnya. Generasi masa kini, yang disebut dengan Generasi Alpha, merepresentasikan sebuah generasi yang kental dengan teknologi internet yang menuntut cukup banyak perubahan dari segi regulasi atau hukum. Perkembangan ini telah mengubah pola komunikasi dan perilaku masyarakat sehingga hukum perlu hadir sebagai mekanisme integratif dalam kehidupan sosial untuk mengendalikan aktivitas ilegal dan mengembalikan keseimbangan sosial. Hukum merupakan kunci untuk mencapai ketertiban dan stabilitas dalam masyarakat yang kompleks demi menjaga kepentingan bersama. ${ }^{3}$

Sebagai fenomena baru, kehadiran mata uang kripto menuntut penyikapan dari aspek hukum. Banyak negara awalnya dibuat terkejut karena penggunaan mata uang ini ternyata cukup massif sehingga membuat hukum terkesan bergerak lambat. Hal serupa pernah terjadi ketika penemuan komputer dan internet. Mulanya pemerintah banyak negara, terutama Amerika Serikat, mengabaikan penggunaan browser atau web untuk mengakses informasi. Tetapi yang terjadi adalah masyarakat berbondong-bondong menggunakannya sehingga memaksa banyak pemerintahan untuk membuat regulasi seperti pembatasan konten pornografi. ${ }^{4}$ Hal ini agaknya meneguhkan perspektif yang memandang bahwa hukum pada dasarnya adalah konservatif. Hukum merupakan polisi yang memelihara "security and order" yang mana ia berubah ketika didahului perubahan nilai-nilai dalam masyarakat. ${ }^{5}$ Padahal hukum selalu dibutuhkan untuk menjadi tumpuan manusia dari ekses-ekses negatif kemajuan teknologi. ${ }^{6}$

Di Indonesia, salah satu exchange atau tempat pertukaran uang kripto adalah Indodax (dengan alamat indodax.com). Hingga 11 Desember 2020 total akun yang terdaftar ada di kisaran 2,3 juta. ${ }^{7}$ Angka ini memang jauh apabila dibandingkan dengan total penduduk Indonesia. Namun menurut Oscar Darmawan, CEO Indodax, transaksi harian di Indodax pernah menembus angka 1 triliyun rupiah ketika anggota atau pemilik akun sekitar 1,1 juta. ${ }^{8}$ Di level global, perkembangan mata uang kripto lebih besar lagi. Dalam situs coinmarketcap.com, sebagai situs yang biasa dirujuk untuk melihat perkembangan mata uang kripto, sampai dengan saat ini terdapat setidaknya 7.950 jenis uang kripto. ${ }^{9}$ Secara keseluruhan nilai kapitalisasinya lebih dari 533 milyar dolar Amerika dengan dominasi pasar oleh Bitcoin - sebagai kripto paling populer-sebesar 62.8\%. Pada Maret lalu harga

2 https://www.forbes.com/sites/bernardmarr/2018/09/02/what-is-industry-4-0-heres-a-supereasy-explanation-for-anyone/\#719d19a19788 (diakses tanggal 28 Januari 2020).

${ }^{3}$ Sharyn L. Roach Anleu. (2000). Law and Social Change, London: SAGE Publications, h. 139.

${ }^{4}$ Aaron Schwabach. (2006). Internet and The Law: Technology, Society and Compromises, California: abc-clio, h. xiv.

5 Perspektif ini mendapat tentangan dari para ahli hukum yang menganggap bahwa hukum sebagai agen modernisasi (agent of modernization) atau dalam bahasa Roscoe Pound adalah "law as an instrument of social engineering". Baca T. Mulya Lubis, Hukum Ekonomi atau "Hukum dan Ekonomi", Jurnal Hukum dan Pembangunan, Vol. 10, No. 5, h. 434.

6 Baca Bakhrul Amal. (2018). Hukum \& Masyarakat: Sejarah, Politik dan Perkembangannya, Yogyakarta: Thafa Media, h. 121.

${ }^{7}$ Diambil dari https://indodax.com/ (diakses tanggal 11 Desember 2020).

8 https:/ finance.detik.com/moneter/d-3895202/transaksi-bitcoin-di-indonesia-tembus-rp-1-thari (diakses tanggal 11 Desember 2020).

${ }^{9}$ Diambil dari https://coinmarketcap.com/ (diakses tanggal 11 Desember 2020). 
Bitcoin ada dalam rentang 5.800 sampai dengan 6.000 dolar Amerika, sementara pada Desember 2020 ini nilainya telah berada dalam kisaran 18.000 dolar Amerika. ${ }^{10}$

Tingginya investasi dalam uang kripto ini mendorong sejumlah negara untuk mengatur penggunaannya, termasuk Indonesia. Indonesia sendiri dikategorikan sebagai negara yang melarang penggunaan cryptocurrency bersama dengan Tiongkok, India, Mesir, Nepal, Maroko, Saudi Arabia dan beberapa negara lainnya. ${ }^{11}$ Sementara negaranegara lainnya seperti Amerika, Jepang, Jerman, Britania Raya, Belanda dan Swiss berkumpul dalam 111 negara yang memberikan status legal bagi cryptocurrency sambil terus mencegah terjadinya money laundring dan penyalahgunaan. Negara-negara lainnya seperti Argentina, Tunisia, Emirat, Peru, Uruguai, Tunisia dan Yordania dianggap belum mengambil sikap atas mata uang digital ini. ${ }^{12}$

Dalam konteks mata uang kripto ini, pemerintah memiliki aturan dasar dalam pengaturan uang sebagaimana tertuang dalam Undang-Undang Nomor 7 Tahun 2011 tentang Mata Uang. Undang-Undang lain yang kerap dirujuk adalah Undang-Undang Nomor 23 Tahun 1999 tentang Bank Indonesia13 dan Undang-Undang Nomor 11 Tahun 2008 tentang Informasi dan Transaksi Elektronik yang lahir kemudian. Namun dalam perkembangannya pemerintah mengeluarkan berbagai kebijakan baru terkait legalitas uang kripto ini dengan sifatnya yang lebih teknis seperti Peraturan Bank Indonesia Nomor 18/40/PBI/2016 tentang Penyelenggaraan Pemrosesan Transaksi Pembayaran, Peraturan Bank Indonesia Nomor 19/12/PBI/2017 tentang Penyelenggaraan Teknologi Finansial, Peraturan Menteri Perdagangan Nomor 99 Tahun 2018 tentang Kebijakan Umum Penyelenggaraan Perdagangan Berjangka Aset Kripto (Crypto Asset) dan Peraturan Badan Pengawas Perdagangan Berjangka Komoditi Nomor 5 Tahun 2019 tentang Ketentuan Teknis Penyelenggaraan Pasar Fisik Aset Kripto (Crypto Asset) di Bursa Berjangka. Dengan beragamnya regulasi tersebut, pembacaan kritis terhadap produk hukum ini tentu sangat diperlukan sebagai upaya memberikan kepastian dalam memfasilitasi roda perekonomian. ${ }^{14}$

\section{METODE PENELITIAN}

Penelitian ini merupakan penelitian hukum normatif dengan pendekatan yuridis normatif. Secara tidak langsung hal ini menggambarkan bahwa penelitian akan menggunakan pendekatan terhadap perundang-undangan (statute approach) sebagai sumber hukum yang telah ada. ${ }^{15}$ Dengan kata lain metode yang digunakan berfokus

${ }^{10}$ Data-data diambil dari coinmarketcap.com (diakses tanggal 11 Desember 2020). Pada data yang diperbarui tanggal 31 Desember 2020, harga bitcoin telah mencapai pada kisaran 28.000 dolar Amerika (coinmarketcap.com, diakses tanggal 31 Desember 2020).

11 https://cryptonews.com/guides/countries-in-which-bitcoin-is-banned-or-legal.htm (diakses tanggal 3 Februari 2020).

12 https://cryptonews.com/guides/countries-in-which-bitcoin-is-banned-or-legal.htm (diakses tanggal 3 Februari 2020).

${ }^{13}$ Telah beberapa kali diubah, terakhir dengan Undang-Undang Nomor 6 Tahun 2009 tentang Penetapan Peraturan Pemerintah Pengganti Undang-Undang Nomor 2 Tahun 2008 tentang Perubahan Kedua atas Undang-Undang Nomor 23 Tahun 1999 tentang Bank Indonesia menjadi Undang-Undang.

14 Baca Muhammad Rusydianta. (Desember 2017). "Dinamika Hukum dan Ekonomi dalam Realitas Sosial di Indonesia (Studi Kritis terhadap Kebijakan Hukum-Ekonomi di Indonesia)". Jurnal RechtsVinding, Vol. 6 No. 3, h. 319.

15 Syprianus Aristeus. (Desember 2018). “Transplantasi Hukum Bisnis di Era Globalisasi: Tantangan bagi Indonesia". Jurnal Penelitian Hukum DE JURE, Vol. 18 No. 4, h. 518. 
pada telaah tekstual terhadap teks-teks hukum. ${ }^{16}$ Selain itu sebagai penelitian hukum normatif maka penelitian ini dapat mencakup penelitian tentang asas-asas hukum, sinkronisasi peraturan perundang-undangan, baik secara vertikal maupun horisontal, sistematika hukum, inventarisasi hukum positif, termasuk usaha penemuan hukum inconcreto. ${ }^{17}$

Dengan desain kualitatif penelitian melakukan pengumpulan data melalui sumber primer yaitu peraturan perundang-undangan, sumber sekunder yaitu seluruh bahan dan karya yang memenuhi unsur kualitatif sebagai penjelasan dari sumber primer, dan sumber tersier yang merupakan data atau bahan pendukung yang sifatnya membantu dalam eksplorasi pembahasan penelitian. Secara umum prosedur penelitian akan melalui tiga tahap, yaitu memformulasikan point of view penelitian, menganalisa masalah-masalah penelitian dan mengambil konklusi.

\section{PEMBAHASAN}

\section{A. Substansi Uang Kripto}

Apakah uang kripto adalah uang? Jika menilik sejarah, diakui atau tidak, uang kripto memang diniatkan sebagai "uang" dengan fungsi sebagaimana uang pada umumnya. Uang kripto dikehendaki dapat digunakan sebagai alat tukar atau standar pengukur nilai. Keberadaan uang kripto selaras dengan kebutuhan global tentang "dunia tanpa perbatasan" (borderless world) yang dapat membentuk negara tanpa batas (a single global society). Bahwa dunia dipandang akan lebih efisien jika tidak dibatasi oleh "politik teritorial" suatu negara, termasuk dalam penggunaan mata uangnya. ${ }^{18}$ Sebagaimana namanya, uang kripto diciptakan melalui enkripsi kriptografi dengan algoritma kompleks yang saling terhubung pada rantai blok yang disebut sebagai block chain. Uang kripto ini bersifat desentralisasi dan karena itu berbeda dengan sistem sentralisasi yang terdapat pada mata uang, termasuk mata uang digital "tradisional" dan sistem perbankan saat ini.

Meskipun sama-sama tersimpan dalam bentuk digital, uang kripto adalah uang digital yang berbeda. Sampai saat ini setidaknya terdapat tiga varian dalam uang digital. Pertama, uang digital yang berbasis pada nilai uang fiat atau fisik. Varian pertama merupakan bentuk "digitalisasi" dari jumlah nilai uang nasabah atau pengguna. Otorisasi masih berada pada pihak perbankan karena terhubung dengan rekening pengguna. Mata uang digital ini sebatas pengalihan wahana, dengan basis nilai tetaplah menggunakan rupiah sebagai mata uang yang disahkan oleh pemerintah. Jenis ini digunakan sebagai AMPK (Alat Pembayaran dengan Menggunakan Kartu) yang meliputi pembayaran via ATM, kartu kredit, kartu debit, serta kartu-kartu sejenisnya. ${ }^{19}$

Kedua, uang digital yang tersimpan dalam dompet digital yang merupakan storedvalue atau prepaid card. Uang ini tidak memerlukan otorisasi dari pihak perbankan atau tidak terhubung dengan rekening pengguna sehingga dapat digunakan secara langsung dengan vendor yang telah menyetujui penggunaannya. Jenis ini tersimpan, misalnya,

${ }^{16}$ Baca Bahder Johan Nasution. (2008). Metode Penelitian Ilmu Hukum, Bandung: Penerbit Mandar Maju, h. 127.

${ }^{17}$ Dikutip dari Syprianus Aristeus, Op.Cit., h. 518.

18 Bandingkan dengan Parulian Siagian. (2001). "Demokratisasi Birokrasi Indonesia dalam Era Globalisasi", dalam Ahmad Gunaryo (Editor), Hukum, Birokrasi dan Kekuasaan di Indonesia, Semarang: Walisongo Research Institute, h. 55-57.

19 Suharni. (2018). "Uang Elektronik (e-Money) Ditinjau dari Perspektif Hukum dan Perubahan Sosial", Jurnal Spektrum Hukum, Vol. 15/No. 1/April 2018, h. 18-19. 
dalam Gopay, OVO, atau E-money yang tersimpan dalam kartu Indomart atau Alfamart. Jenis ini secara umum dikenal sebagai e-money atau uang elektronik yang di Indonesia telah digunakan sebagai pendukung Gerakan Nasional Non Tunai. ${ }^{20}$ Ketiga, uang digital yang dalam penggunaannya tidak lagi membutuhkan perantara. Transaksi dapat terjadi antarpengguna dan tidak perlu diketahui oleh pihak lain. Transaksinya tercatat dalam database jaringan. Uang digital varian ketiga ini yang paling populer adalah Bitcoin sebagai uang digital pertama yang diciptakan oleh sosok anonim Satoshi Nakamoto pada 2009. Setelah meledaknya Bitcoin, uang digital-uang digital lain yang tergabung dalam cryptocurrency bermunculan yang disebut sebagai altcoin atau koin alternatif seperti Ethereum, XRP (Ripple), Dash, Dogecoin, XLM, Cardano dan ribuan lainnya.

Apabila dua uang digital pertama telah dilegalkan oleh pemerintah, bersamaan dengan penerimaan atas kemajuan teknologi, namun jenis yang ketiga masih belum kokoh atau pasti. ${ }^{21}$ William Magnuson ${ }^{22}$ dalam Financial Regulation in the Bitcoin Era yang dipublikasikan dalam Stanford Journal of Law, Business and Finance menilai keberadaan Bitcoin dan alternative coin (alt-coin) memang masih membuka kebutuhan regulasi dalam bidang keuangan. Magnuson hanya mewanti-wanti dalam dinamika ini setiap negara perlu pedoman agar bagaimana regulator hukum mampu mengatur pengaturan modal yang efektif, perlindungan konsumen, dan pencegahan resiko sistemik.23 Magnuson juga mendorong pembuat kebijakan atau hukum untuk mengurangi kekhawatiran terkait mata uang digital dan mulai berkompromi dengan hal baru ini karena bagaimanapun perkembangan digital yang mengarah pada penggunaan cryptocurrency semakin terbuka.

Pandangan Magnuson ini tentu tidak tepat sepenuhnya karena sebagai uang, sebuah entitas harus memenuhi kriteria ada jaminan, disukai umum, nilai yang stabil, mudah disimpan, mudah dibawa, tidak mudah rusak, mudah dibagi dan suplai harus elastis. ${ }^{24}$ Kriteria-kriteria ini tidak dapat dipenuhi oleh uang kripto secara keseluruhan. Paling tidak ada kelemahan jika ukuran kriterianya adalah sebagaimana tersebut. Pertama, uang kripto tidak disahkan oleh negara tertentu sehingga tidak ada yang dapat menjamin penggunaannya. Kedua, uang kripto tidak memiliki nilai yang stabil. Ketiga, uang kripto memiliki ketersediaan yang terbatas.

Hanya saja sebagai produk dari revolusi industri 4.0, uang kripto tidak dapat diabaikan pengaruhnya. Sejarah mencatat bahwa ekonomi telah menciptakan sistem yang mempengaruhi hukum atau bahkan menciptakan hukum berdasarkan pola-pola atau institusionalisasi kegiatan ekonomi itu sendiri. Di Abad Pertengahan kegiatan ekonomi telah menciptakan aturan-aturan bagi pedagang yang merupakan cikal bakal hukum perdagangan (commercial law) di masa modern. ${ }^{25}$ Hal serupa bisa terjadi dalam konteks uang kripto ini.

\footnotetext{
${ }^{20}$ Ibid., h. 19.

21 Dalam penelitiannya, Raden Muhammad Arvy Ilyasa menganggapnya belum memiliki kejelasan hukum. Hal ini seperti tertulis dalam Raden Muhammad Arvy Ilyasa, Legalitas Bitcoin dalam Transaksi Bisnis di Indonesia, Lex Scientia Law Review, Volume 3 No. 2, November 2019. Tetapi kesimpulan ini kurang dapat diterima karena belum menyertakan beberapa regulasi penting lainnya seperti Peraturan Menteri Perdagangan Nomor 99 Tahun 2018 tentang Kebijakan Umum Penyelenggaraan Perdagangan Berjangka Aset Crypto (Crypto Asset).

${ }^{22}$ William Magnuson. (Spring 2018). "Financial Regulation in the Bitcoin Era". Stanford Journal of Law, Business, and Finance, Vol. 23: 2.

${ }^{23}$ Ibid., h. 161.

${ }^{24}$ Kasmir. (2014). Bank dan Lembaga Keuangan Lainnya, Jakarta: PT Raja Grafindo Persada, h. 15-16.

${ }^{25}$ Fabrizio Cafaggi, Antonio Nicita, dan Ugo Pagano (eds.) (2007). Legal Orderings and Economic Institutions, London dan New York: Routledge, h. 49.
} 


\section{B. Analisis Yuridis Normatif atas Uang Kripto}

Pengaturan uang atau mata uang di Indonesia didasarkan pada Undang-Undang Nomor 7 Tahun 2011 tentang Mata Uang. Dalam UU ini uang merupakan "simbol kedaulatan negara yang harus dihormati dan dibanggakan oleh seluruh warga negara Indonesia". Sebagai simbol kedaulatan maka penggunaan uang sebagai "alat pembayaran yang sah" dilakukan di "seluruh wilayah teritorial Indonesia, termasuk kapal dan pesawat terbang yang berbendera Republik Indonesia, Kedutaan Republik Indonesia, dan kantor Perwakilan Republik Indonesia lainnya di luar negeri" (pasal 1). Penggunaan rupiah ini wajib digunakan dalam "(a) setiap transaksi yang mempunyai tujuan pembayaran; (b.) penyelesaian kewajiban lainnya yang harus dipenuhi dengan uang; dan/atau (c.) transaksi keuangan lainnya" (pasal 21 ayat 1) dengan pengecualian terhadap "(a). transaksi tertentu dalam rangka pelaksanaan anggaran pendapatan dan belanja negara; (b). penerimaan atau pemberian hibah dari atau ke luar negeri; (c). transaksi perdagangan internasional; (d). simpanan di bank dalam bentuk valuta asing; atau (e). transaksi pembiayaan internasional" (pasal 21 ayat 2).

Selanjutnya bagi yang melanggar atau tidak menggunakan rupiah dipidana dengan pidana kurungan paling lama 1 (satu) tahun dan pidana denda paling banyak Rp. 200.000.000,00 (dua ratus juta rupiah) (pasal 33). Mata uang rupiah terdiri dari "rupiah kertas" dan "rupiah logam" (pasal 2). Dalam ketentuan UU ini uang kripto jelas tidak dapat dikategorikan sebagai "uang" atau "mata uang". Uang kripto yang beragam jenisnya tidak memiliki dasar hukum untuk digunakan sebagai alat transaksi di Indonesia. Dengan demikian dapat dipahami jika kemudian Bank Indonesia ${ }^{26}$ sebagai Bank Sentral, yang memiliki tanggungjawab untuk menjaga kepercayaan masyarakat terhadap bank mengeluarkan Peraturan Bank Indonesia Nomor 18/40/PBI/ 2016 tentang Penyelenggaraan Pemrosesan Transaksi Pembayaran yang di dalamnya mengatur mengenai uang kripto dengan sebutan sebagai virtual currency.

Peraturan Bank Indonesia di atas merupakan respon terhadap perkembangan fintech (financial technology) di era revolusi industri 4.0. Bank Indonesia menjawab kebutuhan masyarakat dengan mengedepankan "prinsip kehati-hatian dan manajemen risiko yang memadai" dan memperhatikan "perluasan akses, kepentingan nasional dan perlindungan konsumen" (konsideran PBI 18/40/PBI/2016). Dengan peraturan ini sebetulnya Bank Indonesia menjawab ambiguitas legalitas hukum atas uang kripto karena apabila didasarkan pada Undang-Undang Nomor 11 Tahun 2008, uang kripto memenuhi unsur persyaratan minimum sistem elektronik yang dilegalkan di Indonesia. ${ }^{27}$ Peraturan Bank Indonesia Nomor 18/40/PBI/2016 ini amat terbatas dalam mengatur uang kripto. Hanya ada satu pasal yang secara normatif menyatakan bahwa virtual currency dilarang dalam penyelenggaraan sistem pembayaran (pasal 34). Kata

${ }^{26}$ Lihat Undang-Undang Nomor 23 Tahun 1999 tentang Bank Indonesia, dengan perubahan terakhir Undang-Undang Nomor 6 Tahun 2009.

27 Persyaratan minimum itu meliputi kemampuan menampilkan kembali Informasi elektronik dan/atau dokumen elektronik yang sepenuhnya sesuai dengan periode penyimpanan, melindungi ketersediaan, integritas, keaslian, kerahasiaan, dan aksesibilitas informasi elektronik, beroperasi mengikuti prosedur atau penunjuk dalam implementasi elektronik, dilengkapi dengan prosedur atau instruksi yang diumumkan dengan bahasa, informasi, atau simbol yang dapat dipahami oleh pihak-pihak yang terkait, dan memiliki mekanisme berkelanjutan untuk menjaga kebaruan, kejelasan dan prosedur respon atau tanggung jawab pengguna. Disadur dari deskripsi Raden Muhammad Arvy Ilyasa, Op.Cit., h. 122. 
yang digunakan adalah "virtual currency", bukan "cryptocurrency". Namun pernyataan dalam pasal 34 huruf a ini dijelaskan sebagai berikut:

"Yang dimaksud dengan "virtual currency" adalah uang digital yang diterbitkan oleh pihak selain otoritas moneter yang diperoleh dengan cara mining, pembelian, atau transfer pemberian (reward) antara lain Bitcoin, BlackCoin, Dash, Dogecoin, Litecoin, Namecoin, Nxt, Peercoin, Primecoin, Ripple, dan Ven. Tidak termasuk dalam pengertian virtual currency adalah uang elektronik."

Dalam pengertian virtual currency jelas disebutkan beberapa contoh seperti Bitcoin, Dash, Dogecoin, Litecoin dan Ripple yang dikenal sebagai uang kripto yang cukup populer. ${ }^{28}$ Namun dalam peraturan ini virtual currency dimasukkan dalam kelompok sebagai "uang digital". Sehingga dapat dipahami bahwa pelarangan penggunaan mata uang virtual atau uang kripto disebabkan karena tidak diterbitkan oleh otoritas yang berwenang. Oscar Darmawan, CEO dari Indodax, memiliki pendapat yang berbeda karena ia memang tidak memandang uang kripto sebagai "uang digital". Cara kerja uang kripto, menurutnya, seperti sistem pembayaran Visa atau Mastercard. Oscar memberikan penekanan bahwa "Bitcoin (yang merupakan uang kripto paling populer) adalah protokol, bukan bentuk mata uang digital. Ketika suatu negara melegalkan Bitcoin sebagai alat pembayaran, secara otomatis ia akan melibatkan mata uang setempat." 29

Bank Indonesia juga mengeluarkan regulasi lain, yaitu Peraturan Bank Indonesia Nomor 19/12/PBI/2017 tentang Penyelenggaraan Teknologi Finansial. Dalam ketentuannya, Bank Indonesia menekankan kembali bahwa virtual currency dilarang digunakan oleh penyelenggara teknologi finansial (Pasal 8 ayat 2). Penyelenggara finansial selain diwajibkan menggunakan rupiah, salah satunya, diminta untuk "menerapkan prinsip anti pencucian uang dan pencegahan pendanaan terorisme" (Pasal 8 ayat 1 poin e). Dalam penjelasannya disebutkan:

"Yang dimaksud dengan "virtual currency" adalah uang digital yang diterbitkan oleh pihak selain otoritas moneter yang diperoleh dengan cara mining, pembelian, atau transfer pemberian (reward). Larangan melakukan kegiatan sistem pembayaran dengan menggunakan virtual currency karena virtual currency bukan merupakan alat pembayaran yang sah di Indonesia."

Peraturan lain yang juga menyebut mengenai virtual currency adalah Peraturan Bank Indonesia Nomor 20/6/PBI/2018 tentang Uang Elektronik. Sama seperti dua peraturan sebelumnya, peraturan ini merupakan respon dari kebutuhan untuk menanggapi iklim keuangan digital yang semakin kuat. Dalam pasal 62 menyebutkan pemrosesan pembayaran uang elektronik dilarang menggunakan virtual currency dengan penjelasan yang sama, yaitu sebagai uang yang tidak dikeluarkan oleh otoritas moneter. Dengan demikian, membaca regulasi yang dikeluarkan oleh Bank Indonesia dapat dikatakan bahwa baik uang elektronik maupun virtual currency merupakan uang digital.

${ }^{28}$ Jika merujuk pada coinmarketcap.com tiga mata uang teratas dengan kapitalisasi terbesar adalah Bitcoin (535 milyar USD), Ethereum (84 milyar USD) dan Tether (20 milyar USD) dengan keseluruhan kapitalisasi pasar uang kripto sebesar 757 milyar USD. Lihat coinmarketcap.com (diakses pada 31 Desember 2020).

${ }^{29}$ Kalimat ini dikutip dari berita yang ditulis dengan judul "CEO Bitcoin Indonesia Patuhi Larangan BI", CNN Indonesia, Senin 15/01/2018. Link: https://www.cnnindonesia.com/teknologi/20180104184639-185-266776/ceo-bitcoin-indonesiapatuhi-larangan-bi (diakses tanggal 11 April 2020). 
Perbedaannya adalah apabila uang elektronik dipandang sah, sementara virtual currency, dalam hal ini uang kripto, adalah tidak sah sebagai alat pembayaran.

Dari segi yuridis normatif, uang kripto juga menjadi perhatian dari Kementerian Perdagangan. Dengan latar belakang untuk memberikan upaya perlindungan bagi masyarakat dan kepastian hukum terhadap uang kripto, kementerian ini menerbitkan Peraturan Menteri Perdagangan Nomor 99 Tahun 2018 tentang Kebijakan Umum Penyelenggaraan Perdagangan Berjangka Aset Kripto (Crypto Asset). Dalam regulasi ini ternyata terdapat pergeseran ketetapan atau definisi. Uang kripto tidak lagi disebut sebagai "uang digital", melainkan "komoditas". Aset kripto "dapat dijadikan Subjek Kontrak Berjangka yang diperdagangkan di Bursa Berjangka" (pasal 1). Regulasi ini kemudian secara teknis diikuti dengan Peraturan Badan Pengawas Perdagangan Berjangka Komoditi (BAPPEBTI) Nomor 5 Tahun 2019 tentang Ketentuan Teknis Penyelenggaraan Pasar Fisik Aset Kripto (Crypto Asset) di Bursa Berjangka. ${ }^{30}$ Dengan mengubah uang kripto sebagai "barang dagangan", maka keuntungan dan resiko dari pergerakan harga dan nilai tukar dialihkan kepada investor atau anggota Bursa Berjangka. ${ }^{31}$ Namun demikian aset kripto yang dapat diperdagangkan harus memenuhi persyaratan yang ketat. 32

Dengan pergeseran ini regulasi memiliki dua cara ketetapan. Di satu sisi Bank Indonesia mendefinisikannya sebagai "uang digital" yang dilarang dan Kementerian Perdagangan mendefinisikannya sebagai "aset digital" yang dapat diperdagangkan. Otoritas Jasa Keuangan juga bersikap netral atas perbedaan ini dan lebih memilih untuk mengawasi lembaga keuangannya. ${ }^{33}$ Ketidakselarasan ini membuat hukum di Indonesia masih berada dalam ruang "antara". Pemerintah masih memiliki pekerjaan rumah untuk membangun hukum ekonomi yang kuat, terutama dalam regulasi uang kripto ini, dengan mempertimbangkan kesejahteraan dan segala perubahan ekonomi yang terjadi. ${ }^{34}$

\footnotetext{
${ }^{30}$ Dalam pasal 1 Peraturan BAPPEBTI Nomor 5 tahun 2019 ini disebutkan, "Aset Kripto (Crypto Asset) yang selanjutnya disebut Aset Kripto adalah Komoditi tidak berwujud yang berbentuk digital aset, menggunakan kriptografi, jaringan peer-to-peer, dan buku besar yang terdistribusi, untuk mengatur penciptaan unit baru, memverifikasi transaksi, dan mengamankan transaksi tanpa campur tangan pihak lain"

${ }^{31}$ Lihat Undang-Undang Nomor 32 Tahun 1997 tentang Perdagangan Berjangka Komoditi dan perubahannya dalam Undang-Undang Nomor 10 Tahun 2011.

32 Dalam pasal 3 Peraturan BAPPEBTI Nomor 5 tahun 2019 ini diuraikan persyaratan aset kripto yang dapat diperdagangkan adalah "a. berbasis distributed ledger technology; b. berupa Aset Kripto utilitas (utilty crypto) atau Aset Kripto beragun aset (Crypto Backed Asset); c. nilai kapitalisasi pasar (market cap) masuk ke dalam peringkat 500 (lima ratus) besar kapitalisasi pasar Aset Kripto (coinmarketcap) untuk Kripto Aset utilitas; d. masuk dalam transaksi bursa Aset Kripto terbesar di dunia; e. memiliki manfaat ekonomi, seperti perpajakan, menumbuhkan industri informatika dan kompetensi tenaga ahli dibidang informatika (digital talent); dan f. telah dilakukan penilaian risikonya, termasuk risiko pencucian uang dan pendanaan terorisme serta proliferasi senjata pemusnah massal."

${ }^{33}$ Hal ini juga tampak dari sikap Otoritas Jasa Keuangan mengenai mata uang kripto "Libra" yang tengah diinisiasi oleh Facebook. Baca lebih lanjut dalam link ini: https://economy.okezone.com/read/2019/07/19/320/2081212/soal-uang-kripto-libra-milikfacebook-ojk-kami-hanya-awasi-lembaga-keuangannya (diakses 15 April 2020)

34 Baca lebih lanjut Dhaniswara K. Harjono, Konsep Pembangunan Hukum dan Perannya Terhadap Sistem Ekonomi Pasar, Jurnal Hukum No. 4, Vol. 18 Oktober 2011, h. 567-568.
} 


\section{PENUTUP}

Secara yuridis normatif, hukum di Indonesia telah memiliki ketentuan atau regulasi mengenai "uang kripto". Hal ini menunjukkan pemerintah memiliki kesadaran untuk menciptakan rule of law dalam atmosfer baru dari perkembangan kegiatan ekonomi manusia di era digital. Hanya saja dalam ketentuan normatifnya, masih terdapat pertentangan perspektif dalam melihat uang kripto. Di satu sisi Bank Indonesia menempatkannya sebagai "uang digital" sehingga dilarang sebagai alat pembayaran, sementara Kementerian Perdagangan menempatkannya sebagai "aset digital" sehingga diperbolehkan untuk diperdagangkan pada Bursa Berjangka. Dua perspektif hukum dalam melihat objek yang sama tentu menimbulkan kebingungan penggunaan acuan hukum. Dengan demikian, saran dari penelitian ini adalah bahwa perlunya bagi pemerintah untuk melakukan penyelarasan hukum terkait uang kripto dengan melibatkan berbagai stakeholders sehingga tercipta asas dan ketetapan hukum yang harmonis. Dengan demikian hukum menjadi sederhana serta mencerminkan kepastian dan keadilan.

\section{DAFTAR PUSTAKA}

Buku:

Amal. (2018). Bakhrul, Hukum \& Masyarakat: Sejarah, Politik dan Perkembangannya, Yogyakarta: Thafa Media.

Anleu, Sharyn L. Roach. (2000). Law and Social Change, London: SAGE Publications.

Cafaggi, Fabrizio, Antonio Nicita, dan Ugo Pagano (eds.). (2007). Legal Orderings and Economic Institutions, London dan New York: Routledge.

Kasmir. (2014). Bank dan Lembaga Keuangan Lainnya, Jakarta: PT Raja Grafindo Persada.

Nasution, Bahder Johan. (2008). Metode Penelitian Ilmu Hukum, Bandung: Penerbit Mandar Maju.

Schwabach, Aaron. (2006). Internet and The Law: Technology, Society and Compromises, California: abc-clio.

\section{Kontributor Buku:}

Siagian, Parulian. (2001). "Demokratisasi Birokrasi Indonesia dalam Era Globalisasi", dalam Ahmad Gunaryo (Editor), Hukum, Birokrasi dan Kekuasaan di Indonesia, Semarang: Walisongo Research Institute.

\section{Jurnal/ Majalah/ Buletin:}

Aristeus, Syprianus. (Desember 2018). Transplantasi Hukum Bisnis di Era Globalisasi: Tantangan bagi Indonesia. Jurnal Penelitian Hukum DE JURE, Vol. 18 No. 4.

Harjono, Dhaniswara K. (Oktober 2011). Konsep Pembangunan Hukum dan Perannya Terhadap Sistem Ekonomi Pasar. Jurnal Hukum No. 4, Vol. 18.

Ilyasa, Raden Muhammad Arvy. (November 2019). Legalitas Bitcoin dalam Transaksi Bisnis di Indonesia. Lex Scientia Law Review, Volume 3 No. 2.

Lubis, T. Mulya. Hukum Ekonomi atau "Hukum dan Ekonomi", Jurnal Hukum dan Pembangunan, Vol. 10, No. 5.

Magnuson, William. (Spring 2018). Financial Regulation in the Bitcoin Era, Stanford Journal of Law, Business, and Finance, Vol. 23: 2.

Rusydianta, Muhammad. (Desember 2017). Dinamika Hukum dan Ekonomi dalam Realitas Sosial di Indonesia (Studi Kritis Terhadap Kebijakan Hukum-Ekonomi di Indonesia), Jurnal RechtsVinding, Vol. 6 No. 3. 
Suharni. (2018). Uang Elektronik (e-Money) Ditinjau dari Perspektif Hukum dan Perubahan Sosial, Jurnal Spektrum Hukum, Vol. 15/No. 1/April 2018.

Internet/ media online:

https://www.coinbase.com/learn/what-is-cryptocurrency (diakses tanggal 7 April 2020). https:// finance.detik.com/moneter/d-3895202/transaksi-bitcoin-di-indonesia-tembusrp-1-thari (diakses tanggal 22 Maret 2020).

https://coinmarketcap.com (diakses tanggal 31 Desember 2020).

https://cryptonews.com/guides/countries-in-which-bitcoin-is-banned-or-legal.htm (diakses tanggal 3 Februari 2020).

https://cryptonews.com/guides/countries-in-which-bitcoin-is-banned-or-legal.htm (diakses tanggal 3 Februari 2020).

https:/ / finance.detik.com/moneter/d-3895202/transaksi-bitcoin-di-indonesia-tembusrp-1-thari (diakses tanggal 11 Desember 2020).

https://www.cnnindonesia.com/teknologi/20180104184639-185-266776/ceo-bitcoinindonesia-patuhi-larangan-bi (diakses tanggal 11 April 2020).

https://economy.okezone.com/read/2019/07/19/320/2081212/soal-uang-kripto-libramilik-facebook-ojk-kami-hanya-awasi-lembaga-keuangannya (diakses 15 April 2020)

https://www.forbes.com/sites/bernardmarr/2018/09/02/what-is-industry-4-0-heres-asuper-easy-explanation-for-anyone/\#719d19a19788 (diakses tanggal 28 Januari 2020).

\section{Peraturan perundang-undangan:}

Undang-Undang Nomor 11 Tahun 2008 tentang Informasi dan Transaksi Elektronik

Undang-Undang Nomor 23 Tahun 1999 tentang Bank Indonesia

Undang-Undang Nomor 7 Tahun 2011 tentang Mata Uang

Peraturan Badan Pengawas Perdagangan Berjangka Komoditi Nomor 2 Tahun 2019 tentang Penyelenggaraan Pasar Fisik Komoditi di Bursa Berjangka

Peraturan Badan Pengawas Perdagangan Berjangka Komoditi Nomor 3 Tahun 2019 tentang Komoditi yang Dapat Dijadikan Subjek Kontrak Berjangka, Kontrak Derivatif Syariah, dan/atau Kontrak Derivatif Lainnya yang Diperdagangkan di Bursa Berjangka

Peraturan Badan Pengawas Perdagangan Berjangka Komoditi Nomor 5 Tahun 2019 tentang Ketentuan Teknis Penyelenggaraan Pasar Fisik Aset Kripto (Crypto Asset) di Bursa Berjangka

Peraturan Bank Indonesia Nomor 18/40/PBI/ 2016 tentang Penyelenggaraan Pemrosesan Transaksi Pembayaran

Peraturan Bank Indonesia Nomor 19/12/PBI/2017 tentang Penyelenggaraan Teknologi Finansial

Peraturan Bank Indonesia Nomor 20/6/PBI/2018 tentang Uang Elektronik

Peraturan Menteri Perdagangan Nomor 99 Tahun 2018 tentang Kebijakan Umum Penyelenggaraan Perdagangan Berjangka Aset Kripto (Crypto Asset) 